\title{
Preeminence remains a never-ending pursuit
}

This past July in one of the most comprehensive reports to the AOA House of Delegates, Marcelino Oliva, DO, reiterated the goals he had set for the profession and himself during his tenure as AOA president. These goals were to promote the viability of osteopathic hospitals; develop the profession in states with small DO populations; maintain and promulgate osteopathic medical unity; and implement the Task Force recommendations on alternate approval mechanisms for postdoctoral training in an appropriate, timely manner.

He succinctly reported on those things accomplished and problems yet to be overcome. Dr Oliva spoke with candor of his efforts to achieve a preeminent place for osteopathic medicine in the present and future healthcare scenario.

President William Voss, DO, further delineated this goal of preeminence in his inaugural address. He pointed out that in order for the profession to achieve-and maintain-this preeminence, we must plan ahead and anticipate future changes. We must not be mere reactors. We need to be the leaders in a medical revolution, one that Andrew Taylor Still started more than a century ago.

In a recent era of recognition, osteopathic physicians have been accorded the same practice privileges as allopathic physicians. Along with such equality, we share similar problems. For example, the shortage of DOs in some of our smaller states is not a uniquely osteopathic problem. Certain areas in the United States are experiencing healthcare personnel shortages of both DOs and MDs. Nonetheless, the shortage of DOs seems particularly acute, given our tradition of training general practitioners. Numbers alone, however, will not secure the profession a preeminent place in medicine.

Webster's Dictionary defines preeminent as "outstanding;" "to stand out." Osteopathic medicine has a philosophy that is indeed outstanding and does stand out. For years, osteopathic medicine has emphasized the role the musculoskeletal system plays in health and disease. Interest in manual medicine seems to be at an all-time high, both within and outside the profession.

Despite such newfound interest, a danger exists for developing manual medicine as something apart from general medicine. Because of this, a greater emphasis must be placed on how structural diagnosis can be infiltrated into all healthcare analysis and treatment phases. Based on this tenet, the profession has had the foresight to recognize the importance of the general practitioner. Thus, osteopathic medical education is geared toward producing general practitioners. In this area, the profession remains preeminent.

Maintaining this status as well as gaining preeminence in other phases of our profession remains a never-ending, albeit worthy pursuit. 


\section{American Osteopathic Association \\ Continuing Medical Education}

\section{CERTIFICATION OF HOME STUDY}

This is to certify that $\mathrm{I}$,

activity for AOA CME credits.

Please print

completed the following

Type of activity (such as reading or listening)

Name of journal(s) or audio-tape and date(s) of issue(s):

(One-half CREDIT may be granted for each issue or tape)

AOA number

D.O.'s signature

College and year of graduation

Current address (including zip code)

MAIL TO: AOA Division of CME, 142 East Ontario Street, Chicago, Illinois 60611

KEEP A DUPLICATE FOR YOUR RECORDS!

The Home Study form is intended to document individual reading of recognized scientific journals, listening to approved audio-tapes, and other approved home study courses and programs under the criteria described for Category 2-B.

Only one type of home study, such as reading, should be indicated on a single form, though multiple issues of scientific journals may be listed.

This form should not be used, however, when CME quiz cards for the AOA Journal are submitted separately.

\begin{tabular}{|l|}
\hline FOR OFFICE USE ONLY \\
\hline Cat. $\frac{\text { 2-B }}{\text { Date }} \longrightarrow$ \\
Program \# \\
Doctor \# \\
Doctor's Name \\
\hline
\end{tabular}

Please refer to the revised CME GUIDE for additional information. 


\section{Help Your Arthritis Patients Start the Day Buttoned Up.}

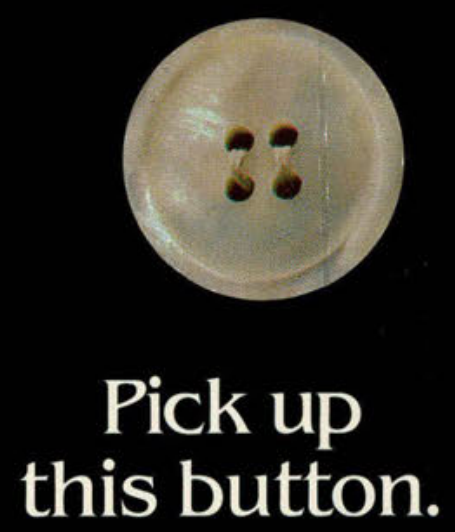

Buttoning a shirt, skirt or dress are just some of the obstacles facing the arthritis patient with morning stiffness.

Morning stiffness turns simple tasks into major challenges.

- Once-daily FELDENE ${ }^{\star}$ (piroxicam) reduces arthritis pain round the clock, ${ }^{1}$ allowing patients to sleep better' and awaken with reduced morning stiffness. ${ }^{2}$

- FELDENE provides round-theclock continuous plasma ${ }^{3}$ and synovial ${ }^{4}$ concentrations on once-daily dosing.
- FELDENE is effective whether taken in the morning or at night. This continuous action with once-daily dosing contrasts with the action of compounds that have shorter plasma halflives and require more frequent dosing to provide comparable therapeutic results. 


\section{Help Your \\ Arthritis Patients Wake Up to Good Mornings}

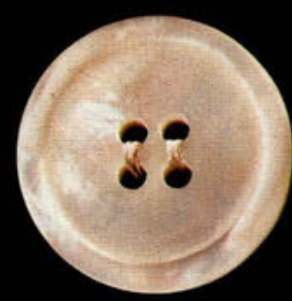

maser ment

As with other NSAIDs, the most common sic effects are Gl-related: in some patients, ulceration, bleeding and perforation may occur.

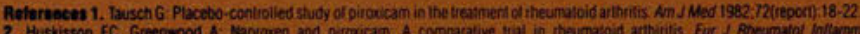

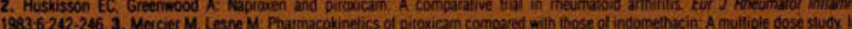

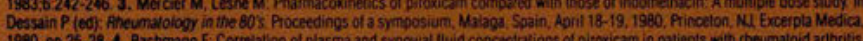

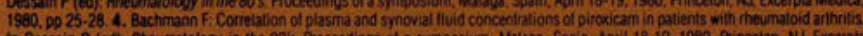
in Dessain P (ed): Aheur
Medica. $1980.0041-44$

\section{Briel Summary}

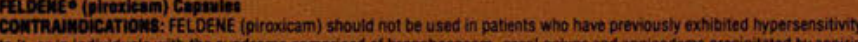
to it, or in individuals with the syndrome comprised of bronchospasm, nasal polyps and angioedema precipitated by aspirit $x$ ocher nonsteroidal anti-inflammatory drugs

Whawiwes: Peptic ulceration, perforation, and G.1. bleeding-sometimes severe, and. in some instances fatal-hav been reported with patients recelving FELDENE. If FELDENE must be given to patients with a history of upper gastrointes tinal tract disease, the patient should be under close supervision (see ADVERSE AEACTIONS). Physicians should remain
alort for uiceration and bleeding in patients treated chronically with NSAIDs even in the absence of previous GI tract

PAECAUTiows: Renal Effects: As with other nonsteroidal anti-inflammatory drugs, long-term administration of piroxican Datimais has resulted in renai papiliary necrosis and other aboormat renal pathology in humans, there have been report: A secong tuephritis with hematuria. proteinuria. and occasionally. nephrotic synerome.

Af second form of renal toxicity has been seen in patients with prerenal conditions leading to a reduction in renal bloor how or blood viume, where the renal prostagiandins have a supportive role in the maintenance of renal perfusion. In thes: overt renal decompensation. Patients at oreatest risk of this reaction ane those with impaired renal function, heart failure. iver dystunction. those taking diuretics, and the eliderly

Because of extensive renal excretion of piroxicam and its biotransformation oroducts fless than $5 \%$ of the daily dose excreted unchanged). lower doses of piroxicam should be anticipated in patents with impaired renal tunction, and the should be carefuliy monitored

Athough other nonsteroidal anti-inflammatory drugs do not have the same direct eflect on platelets that aspitin does all drugs intibiting prostaglandin blosynthesis do intertere with platelet function to some degres.

Because of reports of acverse eye findings with nonsteroidai anti-infianmatory agents; in is recommended that patient:

who develop visual complaints during treatment with FELOENE have ophthalimic evaluatic

As with other nonsteroidar anti-nntiammatory drugs, border ine eievations of one or more liver tests may occur in up to $15 \%$ of patients. A patient with symptoms andjor signs suggesting tiver dysfunction, or in whom abnormal liver tests have occurred, should be evaluated for evidence of the development of more severe bepatic reaction while on therapy wit FELDENE

Severe hepatic reactions, including jaundice and cases of fatal hepalitis, have been reported with fELDENE. Aithough such reactions are rare, if abnormal liver tests persist or worsen. if clinical sigos and symptoms consistent with liver dis Base develop, or il systemic manifestations occur (e.9. eosinophilia, rash, etc.). FELDENE should be discontinued. (SE: also ADVERSE REACTIONS

Aithough at the recommonded dose of $20 \mathrm{mg}$ day of FELOENE increased fecal blood loss due to gastrointestinal irritation die not occut, in about $4 \%$ of the patients to

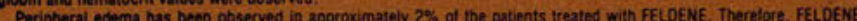

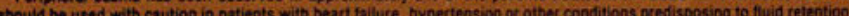

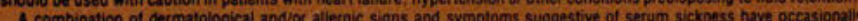

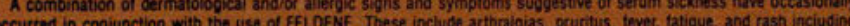
veciculn bullous reactione and extoliathe dermath

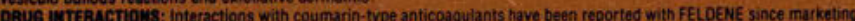
Therelore, physicians should closely monitor patients tor a change in dosage requirements when administering FELDENE to patients on coumarin-type anticoagulants and other highiy protein-bound drugs

Plasma leveis of piroxicam are degressed to approximately $80 \%$ of their normal values when FEL DENE is administeres in coniunction with asoirin ( $3900 \mathrm{mg} / \mathrm{day}$ ), but concomitant administration of antacids has no effect on piroxicam plasm. leveits

Nonsteroidal anti-inflammatory agents, including FEL DENE, have been reported to increase steady state plasma ithiuin leveis. It is recommended that plasma lithium leveis be monitored when initiating. adjusting and discontinuing FEL DENE. Carcinopenesis. Chronit Animal Toxieliy and Impairment of Fertility: Subacute and chronic toxicity studies have bet camied out in rats, mice, dogs, and monkeys

The pathology most orten seen was that craracteristically associated with the animal toxicology of anti-inflammator apents: renal papillary necrosis (see PRECAUTIONS) and gastrountestinal iesions.

In classical studies in labotatory animals, piroxicam dio not snow any leratogenic potent

Reproductive studies reveaied no impairment of tertility in animsis

Progaancy and Nurning Mothern: Like other drugs which inhibit the synthesis and release of prostaplandins. piroxicat administration continued late into pregnancy increased the incidence of dystocia and delayed parturition in animals. Gas trointestinal tract toxicity was increased in pregnant temales in the last trimester of pregnancy compared to non-pregnant temales or fernales in eartier trimesters of pregnan
FELDENE (piroxicam) is not recornmended for use in nursing mother:

Uat in Children: Dosage recommendations and indications for use in children have not been established. AOVERSE AEACnOMS: Gastrointestinal symptorns are the most prominent side eftects, occurring in approximately $20 \%$
of the patients, which in most instances did not interfere with the course of theragy. Ot the pationts experiencing gastro. intestingt eith. Adverse reactions are listed below by body system for all oatients in clinical trials with FEL DENE at doses of 20 mgidor. Ineldence Greater Than 1\%: The foliowing adverse reactions occurred more frequently than 1 in 100 .

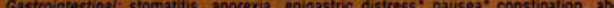
diarthea. abdominal pain. indipestion

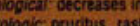

Central Nervous System: diminess, somnoience, vertiog

Urogenilal: BUN and creatinine elevations (see PRECAUTIONS)

\section{body as a Whole: headache, malaiso}

special senses. tunnitis

- Reactions occurring in $3 \%$ to $9 \%$ of patients treated with FELDENE. Reactions occurring in 15 to $3 \%$ of patients att unimarked

Incieence Less Than $1 \%$ (Causal Relationship Probable): The following adverse reactions occurred less trequently that in 100 . The probability exists that there is a causai relationship between fELDENE and these reactions

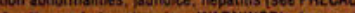
(

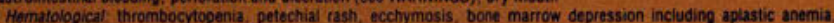
pistaxi:

Owmatologic: sweasing, erythema, bruising. desouamation, extoliative dermatitis, erythema multiforme, toxic epider mat necrolysis Stevens.Johnson syndrome. vesiculo buflious reactions. photoallergic skin reactions

Central Nervous System depression. inemniz nervoieness

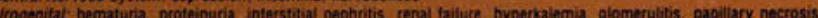
Ghrotic syndrome (see PRECAUTTiONS)

Mody as a Whole gain icolic) tever tlu-like syndrome isee PAECAUTIONS)

Soeciar Senses - swollian eyes blurred vision eve irntations

Car

Metabolic ' hyposlycemia. hyporolycernia, weight increase, weight decreas:

Hypersensitivity: anaphylaxis. bronchospasm, urticaria/anoioedema. vascullits. "serum sickness" (see PRECAUTIONS) Ineidence Less Than 1\% (Causal Relationship unknown: Other adverse reactions were reported with a trequency of less than 1 in 100, but a causal reiationship between FELDENE and the reaction could nol be determine-

Gastrontestinasi pancieaut

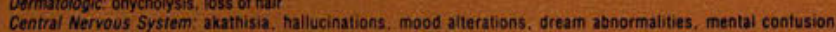

paresthesia:

Urogenital System: dysuria

Body as a Whote: weaknes:

Garciorascurali mespiratory. pa pits

mypersensicinity: positive ANS

Special Senses: transient hearing lo:

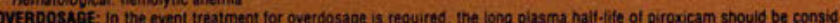
red. The absence of experience with acute overdosage precludes characterization of sequeiae and recommendations $c$ Soctic antidotal efflicacy at this time. It is reasonable to assume that the standard measures of gastric evacuation an jeneral supportive therapy would apply, in addition to supportive measures, the use of activated charcoal may effectivel; ecuce the absorption and reabsorption of piroxicam. Experiments in dogs have demonstrated that the use of multiple-dose 11 hourt with activaled charcoal could reduce the hali-ifte of piroxicam elimination from 27 hours (without charcoal) to as 6 hours atter adiministration of piroviram

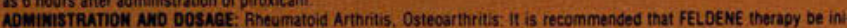
tiated and maintained at a single daly dose of $20 \mathrm{mg}$. If desired. the daly doce may be divided

More detailed orotessional information availabie on reques: 